\title{
Chemical Compositional Signatures of Constituent Minerals of Iron Slags and Ores from the Khmer Monuments
}

\author{
Etsuo Uchida *D, Motoki Murasugi, Ayaka Kuroda and Yusu Lu \\ Department of Resources and Environmental Engineering, Waseda University, 3-4-1 Ohkubo, Shinjuku, \\ Tokyo 169-8555, Japan; motoki.m@suou.waseda.jp (M.M); hati96a@gmail.com (A.K.); \\ wilsonluyusu5133@gmail.com (Y.L.) \\ * Correspondence: weuchida@waseda.jp; Tel.: +81-3-5286-3318
}

Received: 20 May 2019; Accepted: 14 June 2019; Published: 20 June 2019

\begin{abstract}
Iron slags and ores were collected from 22 sites (A to V) in Preah Khan of Kompong Svay, the area surrounding Phnom Daek, and the Angkor monuments. Iron ores were taken from two outcrops in Phnom Daek. The chemical compositions of fayalite and wüstite in the iron slags and magnetite in the iron ores were determined using a scanning electron microscope equipped with an energy dispersive spectrometer. Cluster analysis and principal component analysis using averaged chemical compositional data for fayalite allowed for the investigated slag dumps to be classified into two main groups: Groups 1 and 2. The slag dumps in the area surrounding Phnom Daek and those in the Angkor monuments were classified as Group 1, and those in Preah Khan of Kompong Svay were classified as Group 2, except for sites C and U, which were classified as Group 1. Radiocarbon dating was carried out on 10 charcoal fragments from slag dumps outside the Angkor area. The dating results indicate that iron making in Preah Khan of Kompong Svay was conducted in and after the 13th century except for sites $C$ and $U$, where iron ores may have been supplied from Phnom Daek before the 13th century.
\end{abstract}

Keywords: Khmer monuments; iron slag; iron ore; chemical composition; radiocarbon dating; Phnom Daek

\section{Introduction}

The Khmer monuments consist of Hindu and Buddhist temples built by the Khmer people between the 9th and 15th centuries. The monuments are distributed in Cambodia, Thailand, Laos, and Vietnam. The most famous and important Khmer monuments include the Angkor monuments, which are distributed mainly around Siem Reap City (Figure 1). Because the temples are built mostly of stone, iron tools, such as chisels, were required to quarry stone blocks. A scene in the bas-relief of the Inner Gallery of Bayon shows individuals quarrying stone blocks using long chisel-like sticks (Figure 2a). However, quarries in the Angkor period at the foothill of Mt. Kulen, which are located $\sim 30 \mathrm{~km}$ northeast of the Angkor monuments [1], have oblique quarrying traces on their stone surface (Figure 2b). This may suggest that pickaxes, instead of long chisels, were used to quarry stone blocks (Sato and Yamaguchi, personal communication). However, incomplete bas-reliefs in some Khmer Temples, such as the Terrace of Leper King, indicate that chisels were used to carve the bas-relief. In the Khmer monuments, stone blocks were piled up without cement-like adhesives between blocks. To fasten stone blocks to each other, H-shaped crampons have been used in some places (Figure 2c) [2]. In the Ta Keo and Bakong temples, many holes remain from theft of these iron crampons (Figure 2d). Therefore, iron products were used to construct the Khmer monuments. This suggests that iron making was carried out in the Khmer period. In addition to iron tools for stone quarrying and processing, 
it is expected that iron was used for agricultural and military objectives [3]. Iron fragments that are considered to be part of armatures were found at the Royal Palace in the Angkor monuments [4]. As evidence of iron making, iron slags, which were generated and disposed of in the iron-making process, have been found at the Khmer monuments [5]. Many slag dumps exist in Preah Khan of Kompong Svay [6,7]. Iron ores have also been found in the slag dumps. In this study, iron slags and ores were collected from the slag dumps, and the chemical compositions of constituent minerals were analyzed to determine whether the compositions of the iron slags and ores were different, and to deduce the provenance of the iron ores. In this paper, the term "minerals" was used for convenience for the chemical phases constituting iron slags although they are not natural products [8].

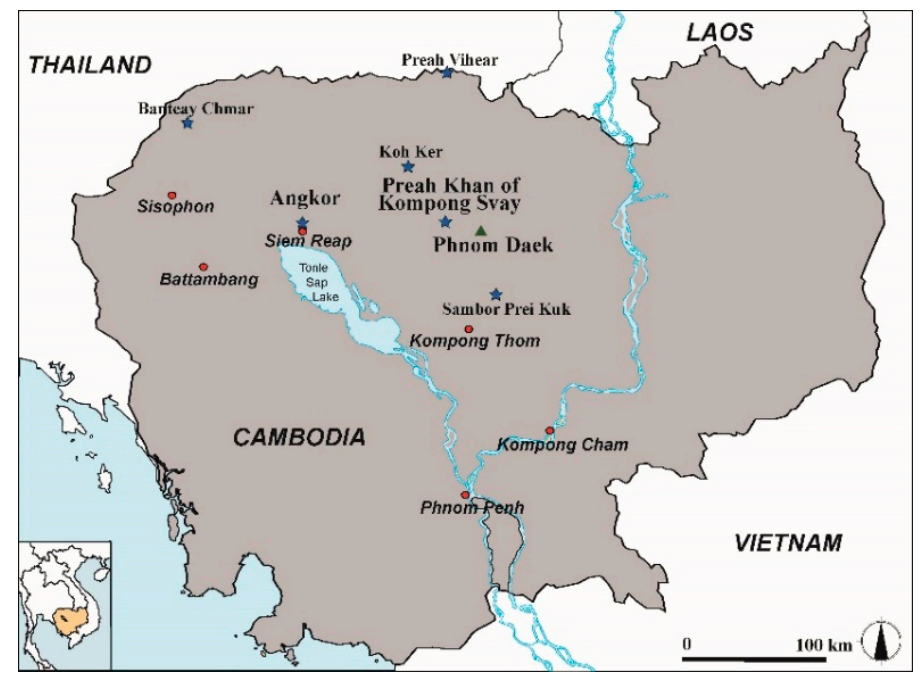

Figure 1. Map of Cambodia showing locations of the Angkor monuments, Preah Khan of Kompong Svay, and Phnom Daek.
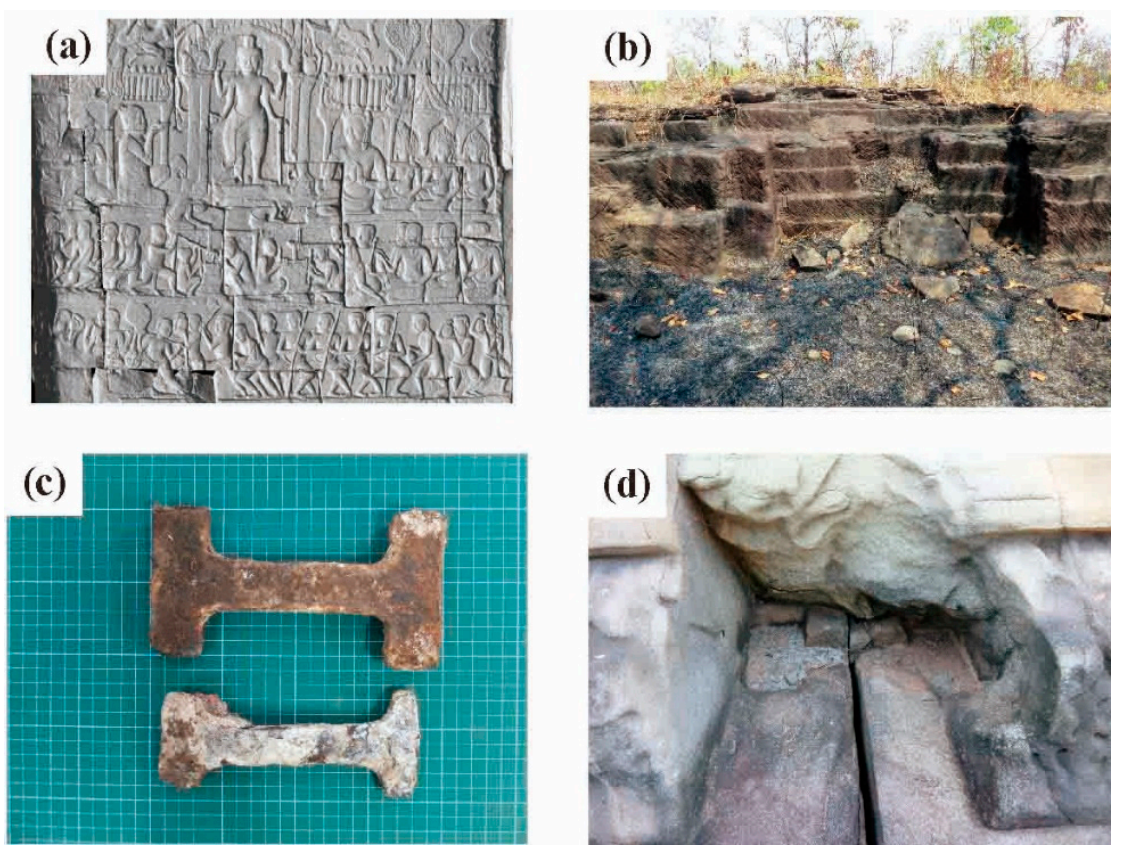

Figure 2. Evidence for iron making and iron products in the Khmer period. (a) Three-dimensional image of bas-relief in the Inner Gallery of Bayon, which shows individuals quarrying stone blocks using long chisel-like sticks, (b) traces on stone surface formed by iron tools during stone quarrying, (c) crampon from the Southeastern Corner Tower in the Outer Gallery of Bayon, and (d) a hole drilled to steal a crampon in Ta Keo. 


\section{Materials and Methods}

\subsection{Materials}

The collection of iron slags and ores was carried out based on the information of Jacques and Lafond [6], Hendrickson et al. [7], Pryce et al. [9], Hendrickson and Evans [10], and local people. Iron slags and ores were collected from 22 sites (Table 1), including seven new sites (D to $H, M$, and V). Figure 3 shows sampling sites of the iron slags and ores in the area surrounding Phnom Daek, and Figure 4 shows those in Preah Khan of Kompong Svay.

Table 1. List of investigated iron slags and ores.

\begin{tabular}{|c|c|c|c|c|}
\hline Sampling Site & Latitude & Longitude & Slag & Iron Ore \\
\hline Ben Sre, PKKS (A) & $13^{\circ} 25^{\prime} 05.5^{\prime \prime} \mathrm{N}$ & $104^{\circ} 44^{\prime} 43.6^{\prime \prime} \mathrm{E}$ & A10 & A8 \\
\hline Ben Sre, PKKS (B) & $13^{\circ} 25^{\prime} 08.8^{\prime \prime} \mathrm{N}$ & $104^{\circ} 44^{\prime} 48.9^{\prime \prime} \mathrm{E}$ & B12, 13 & B11 \\
\hline East Gate of 4th Enclosure, PKKS (C) & $13^{\circ} 24^{\prime} 38.3^{\prime \prime} \mathrm{N}$ & $104^{\circ} 45^{\prime} 11.2^{\prime \prime} \mathrm{E}$ & $\mathrm{C} 11,12,13,15,16$ & $\mathrm{C} 14,15,16$ \\
\hline $\begin{array}{c}\text { South of causeway near East of 3rd } \\
\text { Enclosure, PKKS (D) }\end{array}$ & $13^{\circ} 24^{\prime} 38.6^{\prime \prime} \mathrm{N}$ & $104^{\circ} 45^{\prime} 17.2^{\prime \prime} \mathrm{E}$ & $\mathrm{D} 1,4,5,7,8$ & $\mathrm{D} 10,11,12$ \\
\hline $\begin{array}{c}\text { North of causeway near East of 3rd } \\
\text { Enclosure, PKKS (E) }\end{array}$ & $13^{\circ} 24^{\prime} 42.7^{\prime \prime} \mathrm{N}$ & $104^{\circ} 45^{\prime} 16.0^{\prime \prime} \mathrm{E}$ & $\mathrm{E} 3,5,6$ & $\mathrm{E} 1,2,3,4,5$ \\
\hline Prasat Suor Prat, Angkor monument (G) & $13^{\circ} 26^{\prime} 47.6^{\prime \prime} \mathrm{N}$ & $103^{\circ} 51^{\prime} 38.0^{\prime \prime} \mathrm{E}$ & $\mathrm{G} 1,2,3,4,5,6,7$ & - \\
\hline Bayon, Angkor monument $(\mathrm{H})$ & $13^{\circ} 26^{\prime} 27.5^{\prime \prime} \mathrm{N}$ & $103^{\circ} 51^{\prime} 33.0^{\prime \prime} \mathrm{E}$ & $\mathrm{H} 1,2,3,4$ & - \\
\hline Sre Tomnup, PKKS (I) & $13^{\circ} 24^{\prime} 19.8^{\prime \prime} \mathrm{N}$ & $104^{\circ} 45^{\prime} 31.1^{\prime \prime} \mathrm{E}$ & $\mathrm{I} 3,4,5,6$ & $\mathrm{I} 1,2$ \\
\hline Sre Tomnup, PKKS (J) & $13^{\circ} 24^{\prime} 20.8^{\prime \prime} \mathrm{N}$ & $104^{\circ} 45^{\prime} 38.9^{\prime \prime} \mathrm{E}$ & $\mathrm{J} 2,4,5$ & $\mathrm{~J} 1$ \\
\hline Sre Tomnup, PKKS (K) & $13^{\circ} 24^{\prime} 20.0^{\prime \prime} \mathrm{N}$ & $104^{\circ} 45^{\prime} 39.1^{\prime \prime} \mathrm{E}$ & $\mathrm{K} 2,3,4$ & K1 \\
\hline Trapeang Ach Daek Thom, PKKS (L) & $13^{\circ} 24^{\prime} 08.5^{\prime \prime} \mathrm{N}$ & $104^{\circ} 45^{\prime} 52.4^{\prime \prime} \mathrm{E}$ & $\mathrm{L} 3,4,6$ & $\mathrm{~L} 1,2$ \\
\hline Plau Kuk Daek, PKKS (P) & $13^{\circ} 24^{\prime} 53.8^{\prime \prime} \mathrm{N}$ & $104^{\circ} 45^{\prime} 12.5^{\prime \prime} \mathrm{E}$ & $\mathrm{P} 2,3$ & $\mathrm{P} 1,7,8$ \\
\hline Ben Sre, PKKS (Q) & $13^{\circ} 25^{\prime} 12.0^{\prime \prime} \mathrm{N}$ & $104^{\circ} 44^{\prime} 53.7^{\prime \prime} \mathrm{E}$ & $\mathrm{Q} 2,3,4$ & Q1 \\
\hline Ben Sre, PKKS (R) & $13^{\circ} 25^{\prime} 00.1^{\prime \prime} \mathrm{N}$ & $104^{\circ} 44^{\prime} 31.9^{\prime \prime} \mathrm{E}$ & $\mathrm{R} 2,3,5$ & $\mathrm{R} 1$ \\
\hline Sanlong Java (S) & $13^{\circ} 16^{\prime} 49.2^{\prime \prime} \mathrm{N}$ & $104^{\circ} 59^{\prime} 47.0^{\prime \prime} \mathrm{E}$ & $\mathrm{S} 5,6,8$ & $\mathrm{~S} 1,2,3,4$ \\
\hline Sanlong Tonle Bak $(\mathrm{T})$ & $13^{\circ} 17^{\prime} 16.6-18.1^{\prime \prime} \mathrm{N}$ & $105^{\circ} 00^{\prime} 43.3-48.3^{\prime \prime} \mathrm{E}$ & $\mathrm{T} 1,2,3,4$ & $\mathrm{~T} 1,2,4$ \\
\hline Trapeang Sanlong, PKKS (U) & $13^{\circ} 24^{\prime} 24.8^{\prime \prime} \mathrm{N}$ & $104^{\circ} 45^{\prime} 44.9^{\prime \prime} \mathrm{E}$ & $\mathrm{U} 1,2,3$ & $\mathrm{U} 4,5,6$ \\
\hline Angkor Thom, Angkor monument (V) & - & - & $\mathrm{V} 1$ & - \\
\hline Iron mine 1, Phnom Daek & $13^{\circ} 19^{\prime} 13.7^{\prime \prime} \mathrm{N}$ & $105^{\circ} 00^{\prime} 35.2^{\prime \prime} \mathrm{E}$ & - & MINE1-2, 1-3, 1-7 \\
\hline Iron mine 2, Phnom Daek & $13^{\circ} 19^{\prime} 31.0^{\prime \prime} \mathrm{N}$ & $105^{\circ} 00^{\prime} 45.0^{\prime \prime} \mathrm{E}$ & - & MINE2-2, 2-4, 2-5 \\
\hline
\end{tabular}

Abbreviation: PKKS: Preah Khan of Kompong Svay.

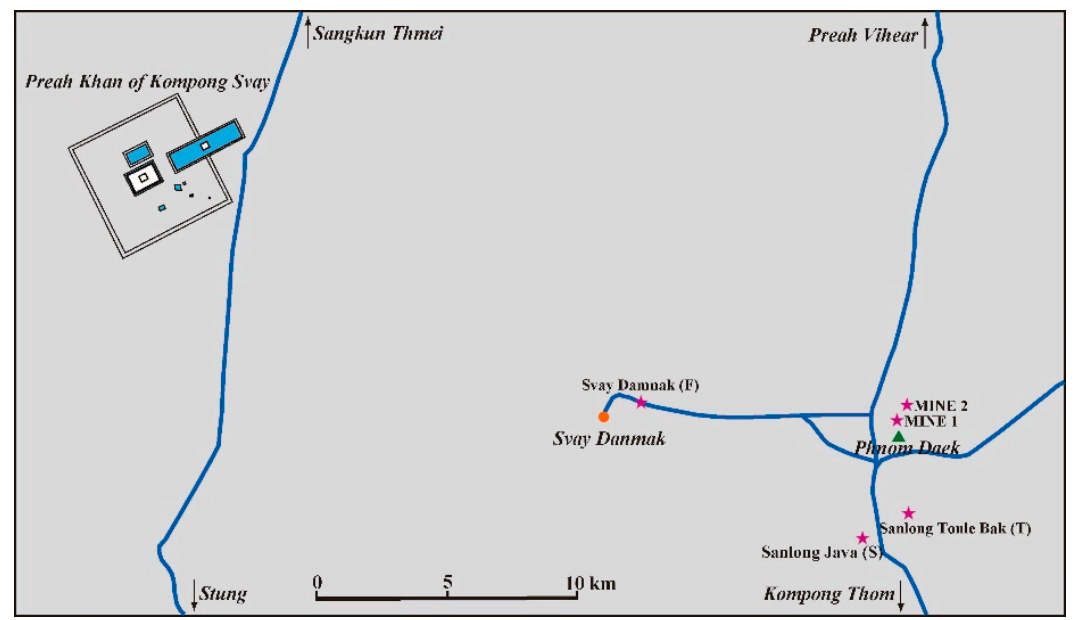

Figure 3. Map showing locations of Preah Khan of Kompong Svay and Phnom Daek. 


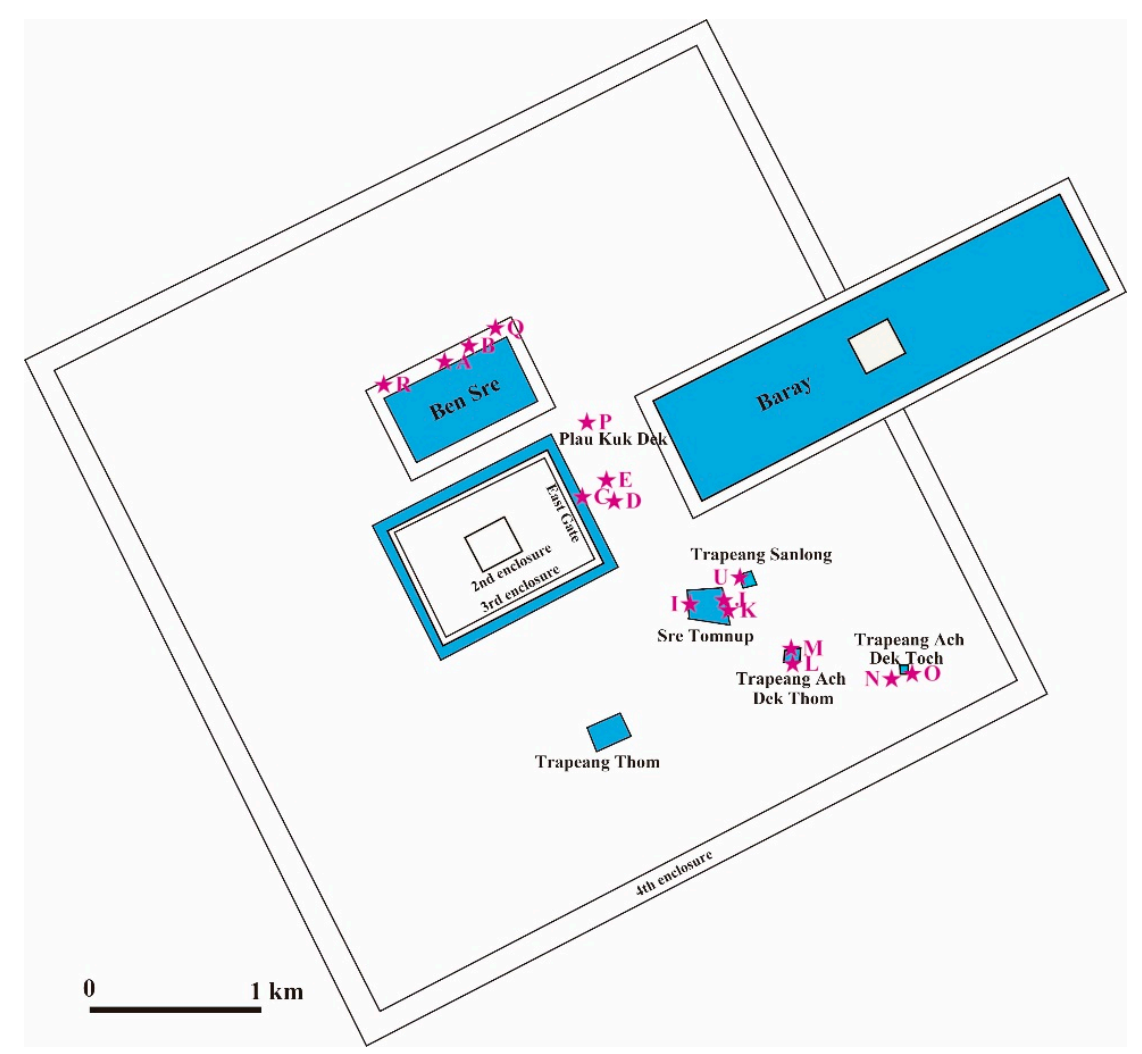

Figure 4. Plan of Preah Khan of Kompong Svay showing sampling sites of iron slags and ores.

Most iron slags and ores were collected from Preah Khan of Kompong Svay, where sampling was performed mainly on the bank of the Baray called Ben Sre, at banks of small ponds between the third and fourth Enclosures, and at three sites near the East Gopura of the third Enclosure.

We collected iron slags and ores from two sites (Sanlong Java (S) and Sanlong Tonle Bak (T)) in the south of Phnom Daek (meaning Iron Mountain), which is situated $30 \mathrm{~km}$ southeast of Preah Khan of Kompong Svay and has been considered as the source of iron ores in the Khmer period [4]. We also collected samples from one site (F) at the roadside near Svay Damnak between Preah Khan of Kompong Svay and Phnom Daek.

We analyzed iron slags from Bayon $(\mathrm{G})$ and Prasat Suor Prat $(\mathrm{H})$ in the Angkor monuments found during the excavation by the Japanese Government Team for Safeguarding Angkor (JSA). One iron slag was collected by a member of JSA in the forest southeast of the Bayon Temple of Angkor Thom $(\mathrm{V})$, and was analyzed. To date, iron ore has not been found at the Angkor monuments.

We sampled iron ores from two outcrops (MINE 1 and MINE 2) in Phnom Daek. The iron deposit in Phnom Daek is of hydrothermal origin and is related to the magnetite-series granodiorite of the late Jurassic to early Cretaceous periods [11].

Fragments of charcoal that was used as fuel and reducing agent rarely remain in the iron slags. Ten charcoal fragments were collected from the iron slags for radiocarbon dating; six samples were from Preah Khan of Kompong Svay; two samples were from Svay Damnak; and two samples were from Sanlong Java.

\subsection{Methods}

After embedding 1-2 cm-diameter iron slag or ore fragments in an epoxy resin (EpoFix, Struers), the mounts were ground with waterproof silicon-carbide papers (\#80, \#180, \#800, \#1200, and \#2400, Struers) and were polished with $3 \mu \mathrm{m}$ and then $\frac{1}{4} \mu \mathrm{m}$ diamond pastes (Struers Diamond Pastes M and $\mathrm{P}$, respectively). 
The polished slag and ore samples were studied under a reflected polarizing microscope, and mineral identification was carried out. The chemical composition analyses of minerals that constituted iron slags and ores were conducted on a polished cross section of each sample using a scanning electron microscope (JSM-6300, JEOL, Tokyo, Japan) equipped with an energy dispersive spectrometer (INCA Energy, Oxford Instruments, Abingdon, UK) (SEM-EDX). The samples were coated with carbon. The accelerating voltage was fixed at $15 \mathrm{kV}$, and the beam current was adjusted so that the X-ray count was 2000 count/s on the Co surface. The analysis time at each point was fixed at $60 \mathrm{~s}$. For each sample, the analysis was carried out on three to 10 grains of fayalite and wüstite, respectively, and 3 to 6 grains of magnetite for each sample.

Radiorcarbon dating was carried out on the charcoal fragments that were collected from the iron slags. Measurements were carried out by Paleo Labo Co., Ltd. [12].

\section{Results}

\subsection{Descriptions of Materials}

\subsubsection{Iron Ores}

Iron ores from the slag dumps and outcrops in Phnom Daek consisted mainly of magnetite and hematite (Figure 5a). We observed a texture where hematite replaced the magnetite in part. Therefore, it is thought that the iron ores consisted mainly of magnetite initially, and that the magnetite changed partly to hematite by hydrothermal alteration. The iron ores are commonly accompanied with quartz, and grandite-series garnet was present in the iron ores that were collected near Svay Damnak. These facts suggest that iron ores were formed by a hydrothermal metasomatism of carbonate rocks, which is related to granitic rocks.
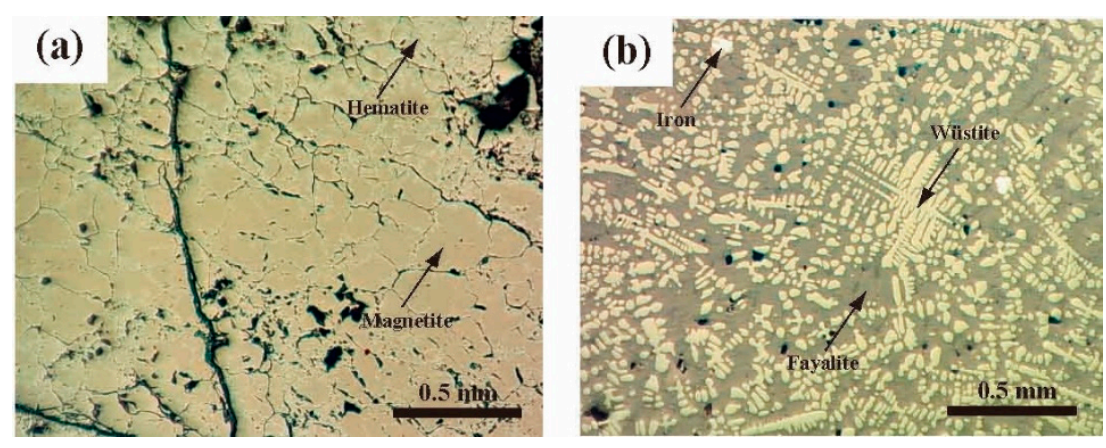

Figure 5. Photomicrographs of iron slags and ores under reflected polarizing microscope. (a) magnetite (grey) partly replaced by hematite (grey white) (sample no. C14-3), and (b) fayalite (dark grey) and wüstite (yellow) in iron slag with a small amount of iron (white) (sample no. D7).

\subsubsection{Iron Slags}

The iron slags consist mainly of fayalite and wüstite (Figure 5b). Wüstite shows a skeletal texture often. In addition to the two minerals, magnetite or metallic iron was observed under the microscope, but these never coexisted. A small amount of hercynite was commonly observed.

Fragments of charcoal that was used as a fuel and as a reducing agent were rarely included in the iron slags. Metallic iron is often seen around the charcoal fragments.

\subsection{Chemical Compositions}

\subsubsection{Fayalite in the Iron Slags}

The ideal chemical formula of fayalite is expressed as $\mathrm{Fe}_{2} \mathrm{SiO}_{4}$. Because fayalite in the iron slags contains some $\mathrm{MnO}$ and $\mathrm{MgO}$, fayalite was treated as a solid-solution in the system fayalite 
(Fa)-tephroite (Tep)-forsterite ( $\mathrm{Fo}$ ). The presence of $\mathrm{CaO}$ up to $18 \mathrm{wt} . \%$ indicates that fayalite (olivine) forms a solid-solution with kirschsteinite $\left(\mathrm{Ca}(\mathrm{Fe}, \mathrm{Mg}, \mathrm{Mn}) \mathrm{SiO}_{4}\right)$. The analytical results are shown in Figure 6 as Fa-Tep-Fo triangular diagrams (Table S1). It was shown experimentally that fayalite forms a continuous solid-solution with tephroite and forsterite under hydrothermal conditions [13].

A cluster analysis was performed using the averaged chemical compositional data for fayalite (Table 2) from each site. Excel Tokei for Windows (Social Survey Research Information Co., Ltd., Tokyo, Japan) was used for a cluster analysis. The result for a cluster analysis using Ward's method is shown in the dendrogram in Figure 7. The slag dumps were classified into two main groups: Groups 1 and 2. Fayalite in the iron slags of Group 1 is rich in $\mathrm{FeO}$ and depleted in $\mathrm{MnO}, \mathrm{MgO}$ and $\mathrm{CaO}$, but that of Group 2 is enriched in $\mathrm{MnO}, \mathrm{MgO}$, and/or $\mathrm{CaO}$. Group 2 could be classified into five subgroups: Groups 2-A to 2-E. Fayalite of Group 2- $\mathrm{A}$ is rich in $\mathrm{CaO}>\mathrm{MnO}=\mathrm{MgO}$; that of Group 2-B is rich in $\mathrm{MnO}=\mathrm{CaO}>\mathrm{MgO}$; that of Group 2-C is rich in $\mathrm{MgO}>\mathrm{MnO}$, but is depleted in $\mathrm{CaO}$; that of Group 2- $\mathrm{D}$ is rich in $\mathrm{MnO}>\mathrm{CaO}$, but is depleted in $\mathrm{MgO}$; and that of Group 2- $\mathrm{E}$ is rich in $\mathrm{MgO}>\mathrm{MnO}>\mathrm{CaO}$.

A principal component analysis (PCA) was also carried out using the data in Table 2 to clarify the factors controlling the classification in the cluster analysis. The results were shown in Figure 8. The slag dumps were classified into two groups the same as the cluster analysis. However, Group 2-D and Group 2-E obtained in the cluster analysis overlap each other on a PC1 vs. PC2 diagram. This is because positions of $\mathrm{MnO}$ and $\mathrm{MgO}$ are close to each other on the PC1 vs. PC2 diagram (Figure 8). On the other hand, they were well separated on a PC1 vs. PC3 diagram.

Slag dumps in the area surrounding Phnom Daek and those in the Angkor monuments were classified as Group 1, and those in Preah Khan of Kompong Svay were classified as Group 2 except for sites $\mathrm{C}$ and $\mathrm{U}$.

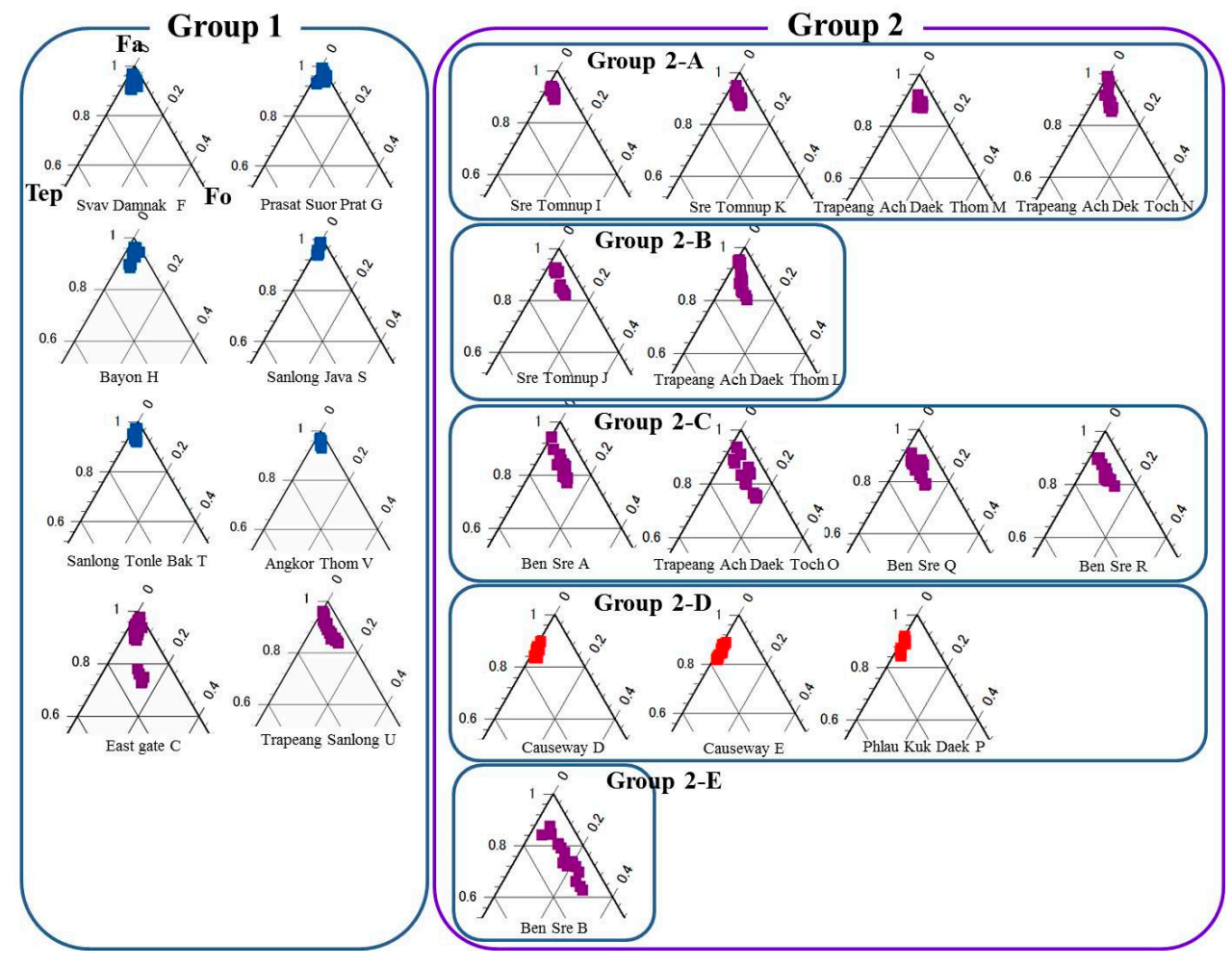

Figure 6. Fayalite (Fa)-Tephroite (Tep)-Forsterite (Fo) triangular diagrams showing chemical composition of fayalite in iron slags from the Khmer monuments. Grouping is based on a cluster analysis using the averaged chemical compositions of fayalite in the iron slags. 
Table 2. Averaged chemical compositional data for fayalite in iron slags at each site (wt.\%).

\begin{tabular}{|c|c|c|c|c|c|c|c|}
\hline Group * & Site & $\mathrm{SiO}_{2}$ & $\mathrm{Al}_{2} \mathrm{O}_{3}$ & $\mathrm{FeO}$ & $\mathrm{MnO}$ & $\mathrm{MgO}$ & $\mathrm{CaO}$ \\
\hline $2-\mathrm{C}$ & Site A & $29.95 \pm 0.40^{* *}$ & $0.28 \pm 0.08^{* *}$ & $60.27 \pm 2.40^{* *}$ & $5.22 \pm 0.79 * *$ & $3.51 \pm 1.38^{* *}$ & $0.76 \pm 0.34 * *$ \\
\hline $2-E$ & Site B & $31.62 \pm 0.69$ & $0.27 \pm 0.36$ & $53.61 \pm 2.64$ & $5.65 \pm 1.01$ & $6.49 \pm 3.43$ & $2.37 \pm 2.26$ \\
\hline 1 & Site C & $27.98 \pm 1.80$ & $0.37 \pm 0.21$ & $67.55 \pm 5.67$ & $2.76 \pm 2.79$ & $0.97 \pm 1.87$ & $0.45 \pm 0.36$ \\
\hline $2-\mathrm{D}$ & Site D & $29.86 \pm 2.01$ & $0.33 \pm 0.19$ & $57.88 \pm 2.42$ & $9.08 \pm 1.51$ & $0.40 \pm 0.16$ & $2.45 \pm 1.68$ \\
\hline 2-D & Site E & $30.12 \pm 0.33$ & $0.29 \pm 0.24$ & $58.63 \pm 0.85$ & $8.74 \pm 1.00$ & $0.47 \pm 0.22$ & $1.75 \pm 1.17$ \\
\hline 1 & Site F & $31.49 \pm 1.66$ & $0.42 \pm 0.37$ & $64.32 \pm 2.22$ & $2.17 \pm 0.92$ & $1.01 \pm 0.48$ & $0.59 \pm 0.23$ \\
\hline 1 & Site G & $30.57 \pm 0.96$ & $0.17 \pm 0.13$ & $66.80 \pm 1.45$ & $0.75 \pm 1.05$ & $0.82 \pm 0.47$ & $0.90 \pm 0.54$ \\
\hline 1 & Site $\mathrm{H}$ & $31.16 \pm 0.49$ & $0.14 \pm 0.11$ & $62.93 \pm 2.40$ & $2.11 \pm 1.53$ & $1.27 \pm 0.38$ & $2.39 \pm 1.10$ \\
\hline $2-\mathrm{A}$ & Site I & $30.18 \pm 0.42$ & $0.13 \pm 0.12$ & $57.33 \pm 5.48$ & $3.30 \pm 0.65$ & $0.90 \pm 0.44$ & $8.17 \pm 5.73$ \\
\hline $2-B$ & Site J & $29.44 \pm 3.77$ & $0.25 \pm 0.38$ & $57.97 \pm 8.57$ & $3.60 \pm 0.92$ & $2.00 \pm 1.32$ & $3.56 \pm 1.94$ \\
\hline $2-A$ & Site K & $32.41 \pm 1.08$ & $0.17 \pm 0.11$ & $53.91 \pm 5.58$ & $3.05 \pm 0.48$ & $1.50 \pm 0.62$ & $8.96 \pm 5.71$ \\
\hline $2-B$ & Site L & $29.54 \pm 0.77$ & $0.29 \pm 0.20$ & $59.85 \pm 5.65$ & $4.45 \pm 1.50$ & $1.76 \pm 0.33$ & $4.11 \pm 5.32$ \\
\hline $2-A$ & Site M & $30.98 \pm 0.66$ & $0.20 \pm 0.30$ & $49.97 \pm 2.67$ & $2.92 \pm 0.43$ & $1.76 \pm 0.33$ & $14.19 \pm 2.20$ \\
\hline $2-A$ & Site $N$ & $30.46 \pm 0.68$ & $0.20 \pm 0.14$ & $58.21 \pm 6.44$ & $2.44 \pm 1.19$ & $1.48 \pm 0.97$ & $7.22 \pm 4.50$ \\
\hline $2-C$ & Site $\mathrm{O}$ & $30.23 \pm 1.20$ & $0.35 \pm 0.26$ & $59.88 \pm 4.02$ & $4.71 \pm 1.13$ & $4.52 \pm 2.45$ & $0.31 \pm 0.12$ \\
\hline 2-D & Site $\mathrm{P}$ & $29.09 \pm 0.47$ & $0.45 \pm 0.32$ & $61.11 \pm 1.13$ & $7.11 \pm 1.51$ & $0.49 \pm 0.26$ & $1.76 \pm 1.12$ \\
\hline $2-C$ & Site $\mathrm{Q}$ & $29.44 \pm 0.52$ & $0.62 \pm 0.21$ & $61.07 \pm 1.31$ & $5.02 \pm 1.12$ & $3.02 \pm 1.02$ & $0.84 \pm 0.54$ \\
\hline $2-C$ & Site R & $30.74 \pm 0.42$ & $0.20 \pm 0.11$ & $59.67 \pm 1.20$ & $5.46 \pm 0.48$ & $3.33 \pm 1.10$ & $0.61 \pm 0.41$ \\
\hline 1 & Site S & $29.96 \pm 0.49$ & $0.58 \pm 0.74$ & $66.24 \pm 1.19$ & $2.17 \pm 0.88$ & $0.33 \pm 0.21$ & $0.72 \pm 0.54$ \\
\hline 1 & Site $\mathrm{T}$ & $29.15 \pm 0.78$ & $0.46 \pm 0.59$ & $66.97 \pm 1.65$ & $2.26 \pm 0.96$ & $0.62 \pm 0.41$ & $0.54 \pm 0.35$ \\
\hline 1 & Site U & $28.27 \pm 2.26$ & $1.04 \pm 1.88$ & $64.67 \pm 2.54$ & $3.50 \pm 0.43$ & $2.16 \pm 1.38$ & $0.34 \pm 0.32$ \\
\hline 1 & Site V & $30.21 \pm 2.12$ & $0.13 \pm 0.12$ & $66.58 \pm 2.75$ & $1.54 \pm 0.35$ & $0.91 \pm 0.32$ & $0.63 \pm 0.37$ \\
\hline
\end{tabular}

* Grouping is based on a cluster analysis using the averaged chemical compositional data for fayalite in iron slags. ** Standard deviation $(2 \sigma)$.

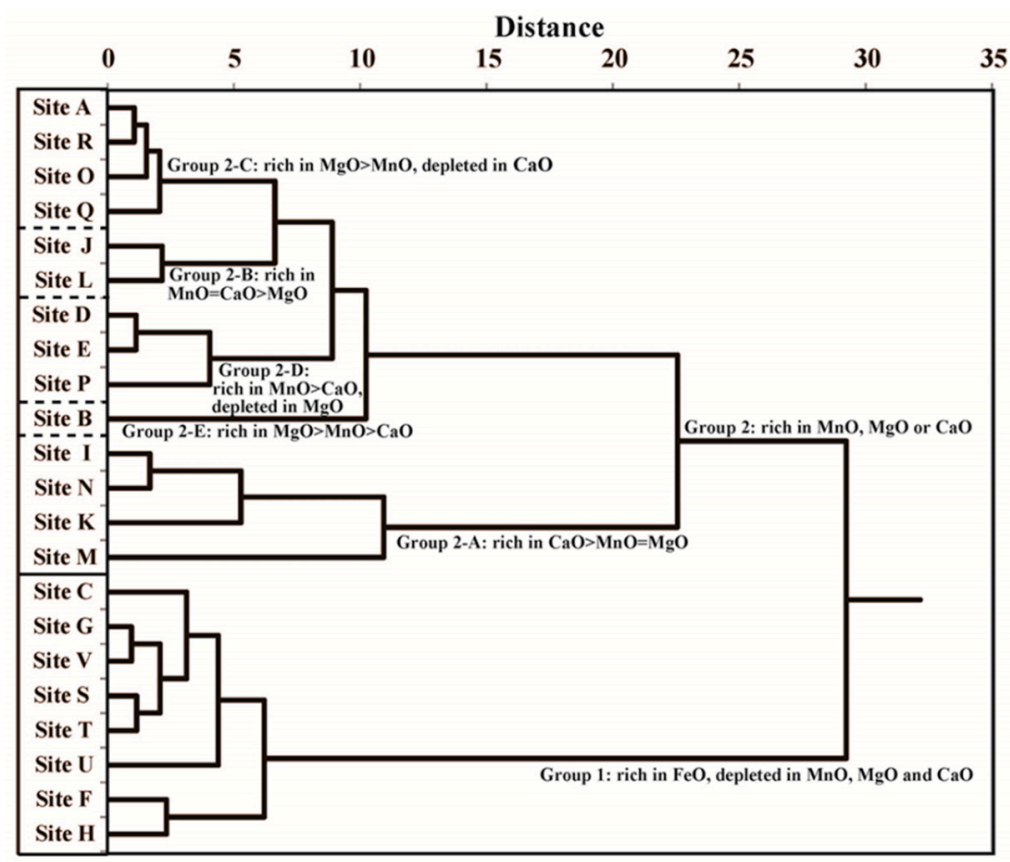

Figure 7. Dendrogram obtained from a cluster analysis (Ward's method), using averaged chemical compositional data for fayalite in iron slags from each site (Table 2). The iron slag sites were classified into two groups: Groups 1 and 2. Group 2 could be classified into five subgroups: Groups 2-A to 2-E. 

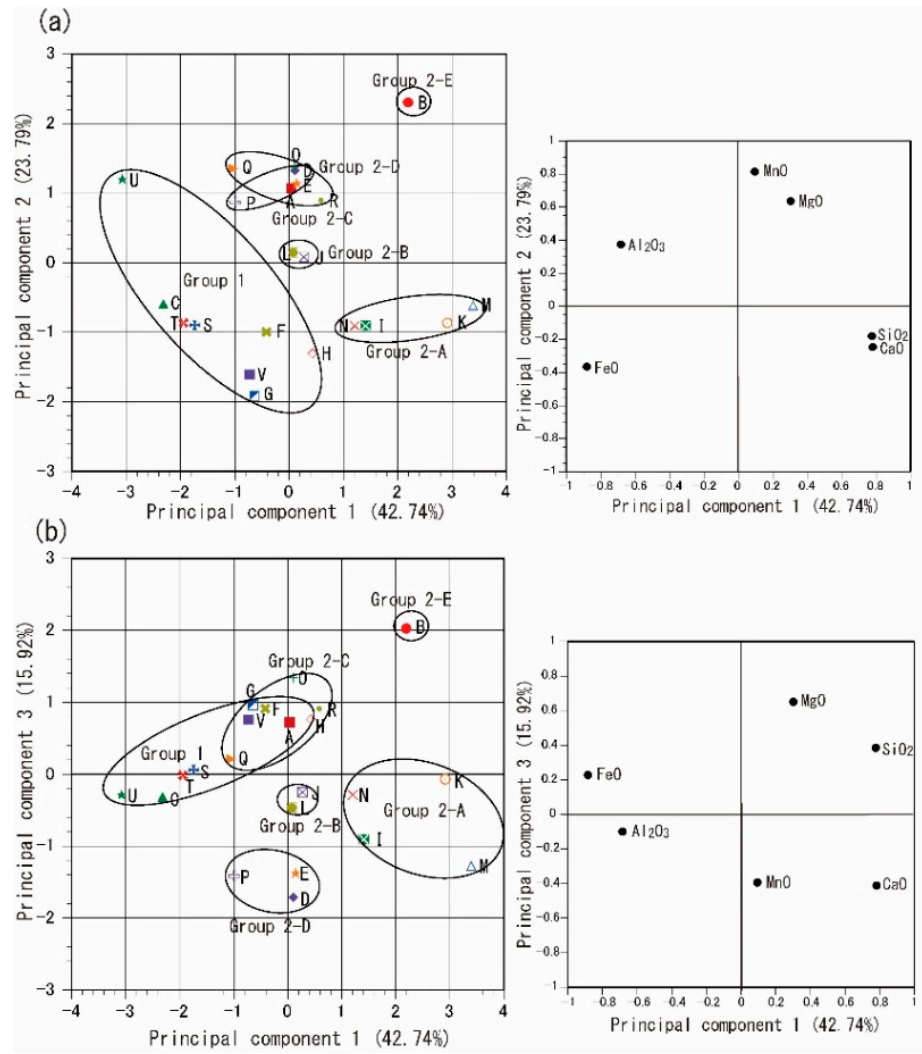

Figure 8. Results of a principal component analysis (PCA), using averaged chemical compositional data for fayalite in iron slags from each site (Table 2). The iron slag sites $\mathrm{A}$ to $\mathrm{V}$ were classified into two groups: Groups 1 and 2. Group 2 could be classified into five subgroups: Groups 2-A, 2-B, 2-C, 2-D, and 2-E. Group 2-C and Group 2-D separated in the cluster analysis overlap each other on a PC1 vs. PC2 diagram by a PCA (a), but they were well separated on a PC1 vs. PC3 diagram (b).

\subsubsection{Wüstite in Iron Slags}

The ideal chemical formula of wüstite is expressed as $\mathrm{FeO}$, or more precisely as $\mathrm{Fe}_{1-\mathrm{x}} \mathrm{O}$. Wüstite in the analyzed slags contains some $\mathrm{MnO}$ and also small amounts of $\mathrm{SiO}_{2}, \mathrm{Al}_{2} \mathrm{O}_{3}, \mathrm{TiO}_{2}$, and $\mathrm{CaO}$ (Table S2). We treated wüstite as a solid-solution between $\mathrm{FeO}$ and $\mathrm{MnO}$. The analytical results are shown and compared in Figure 9 as $\mathrm{FeO}$ vs. MnO diagrams. The $\mathrm{MnO}$ content in wüstite is low compared with fayalite because the partitioning of $\mathrm{MnO}$ into wüstite against fayalite is very low. The $\mathrm{MnO}$ content in wüstite depends on the crystallization temperature and speed. Wüstite in the iron slags of Group 1 is depleted in $\mathrm{MnO}$ (less than $1.5 \mathrm{~mol} \%$ ), except for some iron slags in sites $\mathrm{C}$ and $\mathrm{U}$. However, wüstite in Group 2 is relatively rich in $\mathrm{MnO}$, except for that in Group 2-A, which is rather rich in $\mathrm{CaO}$. The $\mathrm{MnO}$ content ranges from 0 to $4 \mathrm{~mol} \%$ in Group 2. A large overlap was found in the chemical compositions of wüstite between Groups 1 and 2 . 


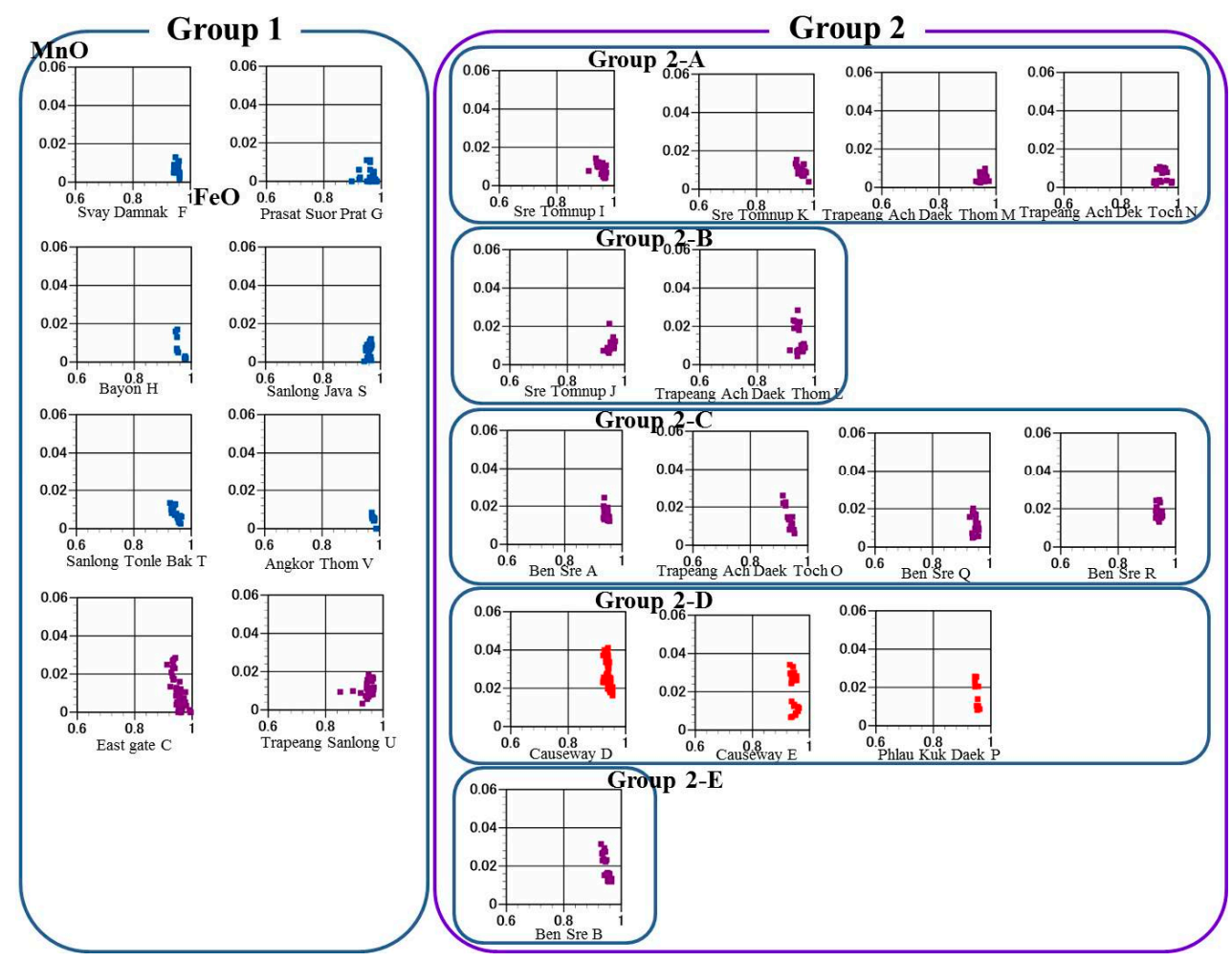

Figure 9. FeO-MnO diagrams showing mole fractions of $\mathrm{FeO}$ and $\mathrm{MnO}$ of wüstite in iron slags from the Khmer monuments. Grouping is based on the averaged chemical compositional data for fayalite in the iron slags.

\subsubsection{Magnetite in Iron Ores}

The analyzed magnetite in the iron ores is composed mainly of $\mathrm{Fe}_{2} \mathrm{O}_{3}, \mathrm{FeO}, \mathrm{MnO}$, and $\mathrm{MgO}$ with small amounts of $\mathrm{SiO}_{2}, \mathrm{Al}_{2} \mathrm{O}_{3}$, and $\mathrm{TiO}_{2}$ (Table S3). Magnetite (Mgt) forms a continuous solid solution with jacobsite (Ja) and magnesioferrite (Mgf) under hydrothermal conditions [14]. The Mgt, Ja, and Mgf contents were calculated as follows. The chemical composition of magnetite can be expressed as $\mathrm{AB}_{2} \mathrm{O}_{4}$. In the calculation of $\mathrm{Mgt}, \mathrm{Ja}$, and $\mathrm{Mgf}$ in magnetite, it was assumed that $\mathrm{Fe}^{2+}, \mathrm{Mn}^{2+}, \mathrm{Mg}^{2+}$, and $\mathrm{Ca}^{2+}$ enter the $\mathrm{A}$ site and that $\mathrm{Fe}^{3+}, \mathrm{Si}^{4+}, \mathrm{T}^{\mathrm{i} 4+}$, and $\mathrm{Al}^{3+}$ enter the $\mathrm{B}$ site. The total analyzed iron was divided into $\mathrm{FeO}$ and $\mathrm{Fe}_{2} \mathrm{O}_{3}$ so that the ratio of $\mathrm{A}$ to $\mathrm{B}$ is 1:2.

The chemical compositions of magnetite in the iron ores were plotted in Mgt-Ja-Mgf triangular diagrams (Figure 10). According to the grouping based on the chemical compositions of fayalite in the iron slags, magnetite of Group 1 contains less than a few $\mathrm{mol} \%$ of Ja $+\mathrm{Mgt}$, except for some iron slags in $\mathrm{C}$ and $\mathrm{U}$ sites, and that of Group 2 contains a large amount of Ja + Mgt up to $40 \mathrm{~mol} \%$, except for Group 2-D. Although fayalite of Group 2-D is rich in Tep, the Ja content in the magnetite of Group 2-D is low, at less than several $\mathrm{mol} \%$. This result is comparable with the Ja content in the magnetite of Group 1. Although the magnetite of Groups 1 and 2-D is depleted in Ja and Mgf, the magnetite of Group 2-D appears to be slightly richer in Ja compared with that of Group 1. 


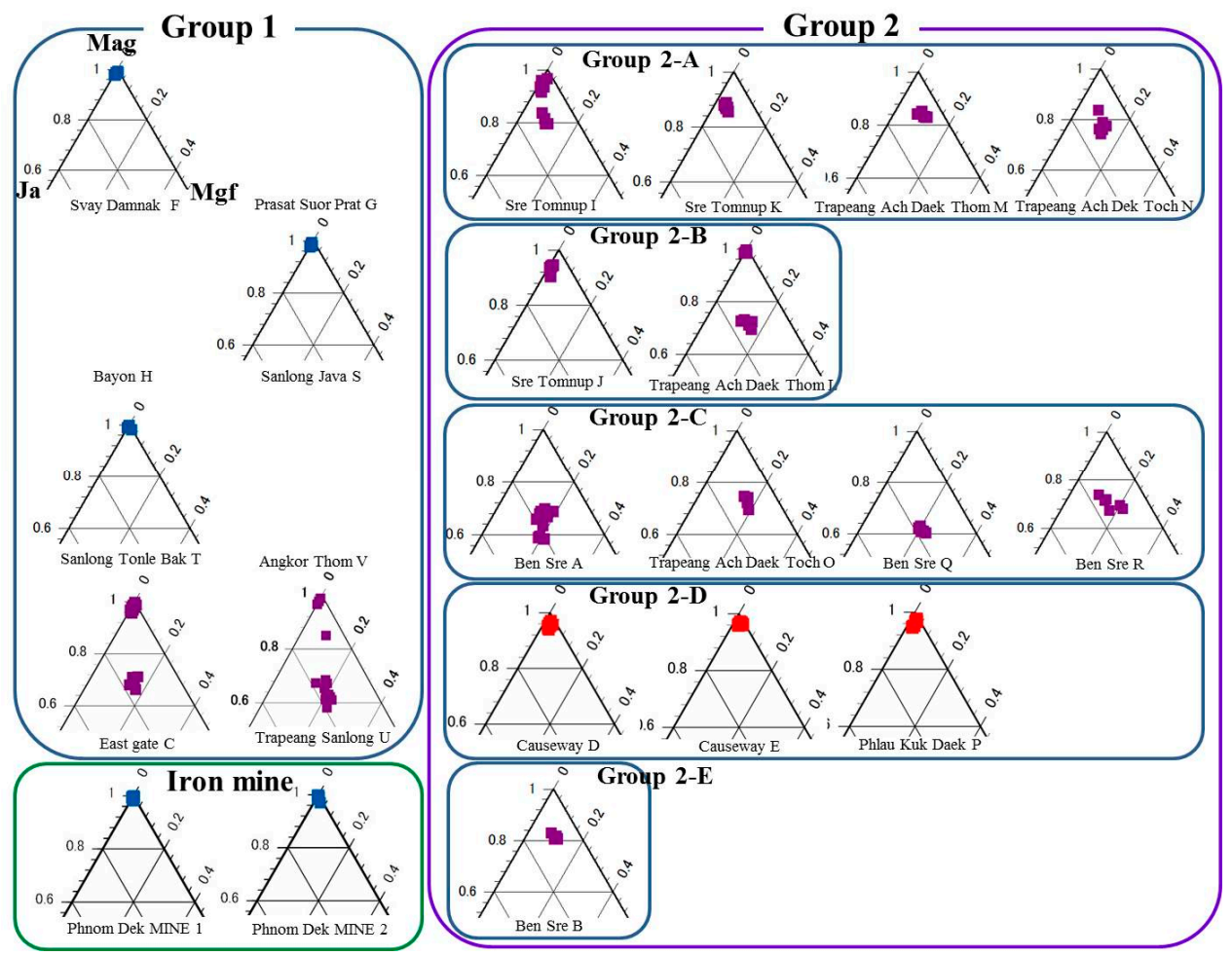

Figure 10. Magnetite (Mgt)-jacobsite (Ja)-magnesioferrite (Mgf) triangular diagrams showing chemical composition of magnetite in iron ores from the Khmer monuments and Phnom Daek. Grouping is based on the averaged chemical compositional data for fayalite in the iron slags.

The contents of Ja and Mgf in magnetite in the iron ores from the outcrops in Phnom Daek are low, at less than several $\mathrm{mol} \%$ in total, and these contents are the same as those of the magnetite of Group 1, but are slightly different from those of the magnetite of Group 2-D.

\subsection{Radiocarbon Dating}

Radiocarbon dating was carried out on 10 charcoal fragments from iron slags at the following sites: two samples from Ben Sre (A) in Preah Khan of Kompong Svay, one sample near the Eastern Gopura (C) in Preah Khan of Kompong Svay, two samples from the south (D) and north sides (E) of the causeway near the Eastern Gopura in Preah Khan of Kompong Svay, one sample from Phlau Kuk Daek (P) in Preah Khan of Kompong Svay, two samples from Svay Damnak (F), and two samples from Sanlong Java (S) (Figure 3; Figure 4).

The radiocarbon-dating results are summarized in Table 3 . The $\delta^{13} \mathrm{C}$ values were used in the calculation of the radiocarbon age and error to correct for isotopic fractionation in nature. Only two charcoal samples from Svay Damnak (F) were older than the 13th century, that is, from the 11th to 12th centuries. Other samples were from the 13th century and later. The two samples from Sanlong Java (S) were youngest, from the 17th to 20th centuries. 
Table 3. Radiocarbon ages for charcoal fragments from iron slags from the Khmer monuments.

\begin{tabular}{|c|c|c|c|c|c|c|}
\hline \multirow{2}{*}{ Lab No. (PLD-) } & \multirow{2}{*}{ Sample No. } & \multirow{2}{*}{ Sampling Point } & \multirow{2}{*}{$\delta^{13} \mathrm{C}(\% \mathrm{o})$} & \multirow{2}{*}{${ }^{14} \mathrm{C}$ Age $(\mathrm{yrBP} \pm 1 \sigma)$} & \multicolumn{2}{|c|}{ Calibrated ${ }^{14} \mathrm{C}$ Age (Probability) } \\
\hline & & & & & $1 \sigma$ & $2 \sigma$ \\
\hline PLD-19382 & No. A-1 & Ben Sre, Preah Khan of Kompong Svay & $-28.65 \pm 0.14$ & $390 \pm 20$ & $1451-1486 \mathrm{cal}$ AD (68.2\%) & $\begin{array}{l}1445-1515 \mathrm{cal} \text { AD }(82.8 \%) \\
1600-1618 \mathrm{cal} \text { AD }(12.6 \%)\end{array}$ \\
\hline PLD-19383 & No. A-2 & Ben Sre, Preah Khan of Kompong Svay & $-28.57 \pm 0.15$ & $390 \pm 20$ & $1450-1485 \mathrm{cal}$ AD (68.2\%) & $\begin{array}{l}\text { 1445-1513 cal AD (84.2\%) } \\
1601-1617 \mathrm{cal} \text { AD }(11.2 \%)\end{array}$ \\
\hline PLD-30928 & No. C-1 & $\begin{array}{l}\text { near East Gate of 3rd Enclosure, Preah } \\
\text { Khan of Kompong Svay }\end{array}$ & $-24.01 \pm 0.29$ & $535 \pm 20$ & $1400-1425 \mathrm{cal}$ AD (68.2\%) & $\begin{array}{l}\text { 1326-1344 cal AD (12.4\%) } \\
1394-1432 \mathrm{cal} \mathrm{AD}(83.0 \%)\end{array}$ \\
\hline PLD-30929 & No. D-1 & $\begin{array}{c}\text { South of causeway near East Gate of 3rd } \\
\text { Enclosure, Preah Khan of } \\
\text { Kompong Svay }\end{array}$ & $-24.51 \pm 0.35$ & $440 \pm 20$ & $1436-1453 \mathrm{cal}$ AD (68.2\%) & $1426-1470 \mathrm{cal} \mathrm{AD}(95.4 \%)$ \\
\hline PLD-30930 & No. E-1 & $\begin{array}{c}\text { North of causeway near East Gate of 3rd } \\
\text { Enclosure, Preah Khan of } \\
\text { Kompong Svay }\end{array}$ & $-28.54 \pm 0.29$ & $745 \pm 20$ & $1263-1278 \mathrm{cal}$ AD (68.2\%) & $1248-1286 \mathrm{cal} \mathrm{AD}(95.4 \%)$ \\
\hline PLD-32588 & No. F-1-2 & Svay Damnak & $-26.72 \pm 0.31$ & $965 \pm 20$ & $\begin{array}{l}1025-1045 \mathrm{cal} \text { AD }(30.2 \%) \\
1095-1120 \mathrm{cal} \text { AD }(32.1 \%) \\
1141-1147 \mathrm{cal} \text { AD }(5.9 \%)\end{array}$ & $\begin{array}{l}1020-1054 \mathrm{cal} \text { AD }(35.6 \%) \\
1078-1154 \mathrm{cal} \mathrm{AD}(59.8 \%)\end{array}$ \\
\hline PLD-32589 & No. F-4 & Svay Damnak & $-24.30 \pm 0.19$ & $940 \pm 15$ & $\begin{array}{l}1036-1050 \text { cal AD }(12.5 \%) \\
1083-1126 \text { cal AD }(41.3 \%) \\
1136-1151 \text { cal AD }(14.3 \%)\end{array}$ & $\begin{array}{l}1030-1059 \mathrm{cal} \mathrm{AD}(21.1 \%) \\
1064-1154 \mathrm{cal} \mathrm{AD}(74.3 \%)\end{array}$ \\
\hline PLD-30931 & No. P-1 & $\begin{array}{l}\text { Phlau Kuk Daek, Preah Khan of } \\
\text { Kompong Svay }\end{array}$ & $-27.36 \pm 0.30$ & $635 \pm 20$ & $\begin{array}{l}1297-1315 \text { cal AD (25.1\%) } \\
1356-1388 \text { cal AD ( } 43.1 \%)\end{array}$ & $\begin{array}{l}\text { 1289-1325 cal AD (38.1\%) } \\
1345-1394 \mathrm{cal} \text { AD (57.3\%) }\end{array}$ \\
\hline PLD-32476 & No. S-1 & Sanlong Java & $-27.20 \pm 0.15$ & $205 \pm 20$ & $\begin{array}{l}1661-1671 \mathrm{cal} \text { AD }(15.3 \%) \\
1778-1799 \mathrm{cal} \text { AD }(34.3 \%) \\
1942-1954 \mathrm{cal} \mathrm{AD}(18.6 \%)\end{array}$ & $\begin{array}{l}\text { 1652-1681 cal AD (26.0\%) } \\
1738-1751 \mathrm{cal} \text { AD (3.4\%) } \\
1762-1802 \mathrm{cal} \text { AD (45.0\%) } \\
1937-1955 \mathrm{cal} \text { AD (21.0\%) }\end{array}$ \\
\hline PLD-32477 & No. S-2 & Sanlong Java & $-26.15 \pm 0.18$ & $140 \pm 20$ & $\begin{array}{c}1680-1695 \mathrm{cal} \text { AD }(11.3 \%) \\
1726-1739 \mathrm{cal} \text { AD }(9.6 \%) \\
1743-1763 \mathrm{cal} \text { AD }(11.8 \%) \\
1801-1813 \mathrm{cal} \text { AD }(8.7 \%) \\
1837-1842 \mathrm{cal} \text { AD }(2.7 \%) \\
1853-1860 \mathrm{cal} \text { AD }(3.6 \%) \\
1860-1867 \mathrm{cal} \text { AD }(3.8 \%) \\
1874-1875 \mathrm{cal} \text { AD }(0.6 \%) \\
1918-1938 \mathrm{cal} \text { AD }(16.1 \%)\end{array}$ & $\begin{array}{c}1670-1700 \mathrm{cal} \text { AD }(15.2 \%) \\
1702-1707 \mathrm{cal} \text { AD }(0.6 \%) \\
1719-1779 \mathrm{cal} \text { AD }(29.5 \%) \\
1799-1819 \mathrm{cal} \text { AD }(11.0 \%) \\
1823-1825 \mathrm{cal} \text { AD }(0.3 \%) \\
1832-1881 \mathrm{cal} \text { AD }(20.2 \%) \\
1914-1943 \mathrm{cal} \text { AD }(18.2 \%) \\
1952-1953 \mathrm{cal} \text { AD }(0.3 \%) \\
1954-1955 \mathrm{cal} \text { AD }(0.1 \%)\end{array}$ \\
\hline
\end{tabular}




\section{Discussion}

\subsection{Sources of Iron Ores}

The slag dumps could be classified into two main groups by a cluster analysis and a principal component analysis using the averaged chemical compositional data for fayalite in the iron slags. The slag dumps of Group 2 are located in Preah Khan of Kompong Svay. Except for Group 2-D, they are located at the waterside, such as reservoirs, ponds, and a moat. The slag dumps of Group 1 are located in places other than Preah Khan of Kompong Svay except for sites $C$ and $U$, that is, in the area surrounding Phnom Daek (Sanlong Tonle Bak (T), Sanlong Java (S), and Svay Damnak (F)), and in the Angkor area (Bayon (H), Prasat Suor Prat (G), and Angkor Thom (V)).

Fayalite in the iron slags, and magnetite in the iron ores from the slag dumps of Group 1 are depleted in $\mathrm{MnO}, \mathrm{MgO}$, and $\mathrm{CaO}$ except for some iron slags from sites $\mathrm{C}$ and $\mathrm{U}$. $\mathrm{MnO}, \mathrm{MgO}$, and/or $\mathrm{CaO}$ contents were relatively high in minerals in the slag dumps of Group 2, except for magnetite in the iron slags of Group 2-D. The chemical compositions of fayalite in Sre Tomnap (I and K) and Trapeang Ach Daek Thom (M) of Group 2-A are similar to those of the slag dumps of Group 1 in Figure 6, but fayalite in these slag dumps is rich in $\mathrm{CaO}$, and the chemical compositions of magnetite in these slag dumps are considerably different from those of the slag dumps of Group 1.

In terms of the chemical compositions of wüstite, Groups 1 and 2 exhibit a similar tendency to that of fayalite with some exceptions: wüstite in Group 1 is depleted in $\mathrm{MnO}$ except for some iron slags from sites $\mathrm{C}$ and $\mathrm{U}$, but that in Group 2 is relatively rich in $\mathrm{MnO}$, except for Group 2-A. The $\mathrm{MnO}$ content of wüstite from sites $C$ and $U$ appears to lie between that of Groups 1 and 2. Wüstite in Group 2-A is rich in $\mathrm{CaO}$ compared with that of Group 1.

Fayalite in Group 2-D contains almost no $\mathrm{MgO}$, but is rich in $\mathrm{MnO}(7-20 \mathrm{~mol} \%)$, which is different from that of Groups 2-A to 2-C and 2-E. The MnO content of wüstite in Group 2-D is high, and is similar to that of Groups 2-B, 2-C, and 2-E. However, magnetite in Group 2-D is depleted in $\mathrm{MnO}$ and $\mathrm{MgO}$ but is slightly rich in $\mathrm{MnO}$ and $\mathrm{MgO}$ compared with the magnetite of Group 1, except for sites $\mathrm{C}$ and U.

The iron-ore samples were taken from two outcrops (MINE 1 and MINE 2) in Phnom Daek. These iron ores consist mainly of magnetite, and show a texture under a reflected polarizing microscope in which magnetite is replaced partially by hematite. This texture is similar to that of iron ores from the slag dumps. Magnetite in the iron ores from the outcrops in Phnom Daek contains almost no MgO or $\mathrm{MnO}$ and has a similar chemical signature to the iron ores from the slag dumps of Groups 1 and 2-D. This may suggest that the iron ores of Groups 1 and 2-D have been supplied from Phnom Daek. However, because magnetite of Group 2-D tends to be slightly rich in $\mathrm{MgO}$ and $\mathrm{MnO}$ compared with that of Group 1 and Phnom Daek, it is possible that the iron ores of Group 2-D have been supplied from an iron mine other than Phnom Daek.

Pryce et al. [9] conducted whole chemical analysis using SEM-EDX for iron slags and ores from Ben Sre (A and B), Sanlong Java (S), Sanlong Tonle Bak (T), and Trapeang Ach Daek Toch (O), and also for iron ores from Phnom Daek. They found that the iron slags from Sanlong Java (S) and Sanlong Tonle Bak (T), which belong to Group 1 of this study, contained lower $\mathrm{MnO}, \mathrm{MgO}$, and $\mathrm{CaO}$ contents, but the $\mathrm{MnO}, \mathrm{MgO}$, and $\mathrm{CaO}$ contents of the iron slags from Ben Sre (A and $\mathrm{B}$ ), which were classified as Groups 2-C and 2-E, respectively, were higher. The $\mathrm{MnO}, \mathrm{MgO}$, and $\mathrm{CaO}$ contents of the iron slags from Trapeang Ach Daek Toch $(\mathrm{O})$ range from high to low. The iron ores from Phnom Daek were depleted in $\mathrm{MnO}, \mathrm{MgO}$, and $\mathrm{CaO}$. The chemical compositional results for fayalite in iron slags and magnetite in iron ores obtained in this study are consistent with the chemical compositional results for iron slags and ores by Pryce et al. [9].

Magnetite can contain $\mathrm{MnO}(\mathrm{Ja})$ and $\mathrm{MgO}(\mathrm{Mgf})$ at any ratio under high-temperature and high-pressure conditions. However, because natural hydrothermal magnetite is rarely enriched in $\mathrm{MnO}$ and $\mathrm{MgO}$, it can be said that the iron ores of Group 2, except for Group 2-D have a characteristic chemical composition. The magnetite grain size in the iron ores is medium to large and the iron ores 
are accompanied frequently by quartz. Therefore, we deduce contact metasomatism of carbonate rocks that are rich in $\mathrm{MnO}$ and $\mathrm{MgO}$ through a hydrothermal fluid derived from granitic magma as the formation environment of the iron ores of Group 2, except for Group 2-D. No information exists on iron mines in Cambodia that produce magnetite that is rich in $\mathrm{MnO}$ and $\mathrm{MgO}$.

\subsection{Dating for Charcoal Fragments from Iron Slags}

Radiocarbon dating was performed on 10 charcoal fragments from the slag dumps, on 15 charcoal fragments by Hendrickson et al. [7], and on 10 charcoal fragments by Pryce et al. [9]. No charcoal fragments were present in the iron slags from the Angkor monuments.

Except for the slag dump (C) near the Eastern Gopura, the charcoal fragments from Preah Khan of Kompong Svay showed radiocarbon ages from the 13th century and later (Table 3). The ages for the iron slags of the slag dump (C) range from the 10th to the 17th centuries.

Relatively old ages were obtained for the iron slags from Sanlong Tonle Bak (T) and Svay Damnak (F) from the 7th to the 12th centuries and the 11th to the 12th centuries, respectively. In contrast, the iron slags from Sanlong Java (S) showed younger ages from the 17th to 20th centuries. Many charcoal fragments originated after 1431 when the Angkor Empire had fallen. This suggests that iron making was practiced during the post-Angkor period.

Because Phnom Daek is located close to Preah Khan of Kompong Svay, it has been thought that iron ores were supplied from Phnom Daek to Preah Khan of Kompong Svay during the Angkor period. The chemical compositions of constituent minerals of the iron slags and ores indicate that the iron ores used in Preah Khan of Kompong Svay, except for part of the iron ores in sites C and U, were supplied from an iron mine that is different from Phnom Daek. The radiocarbon-dating results indicate that iron ores rich in $\mathrm{MnO}$ and $\mathrm{MgO}$ were supplied in and after the 13th century from iron mines other than Phnom Daek. It is highly likely that the iron ores were supplied from Phnom Daek to Sanlong Java, Sanlong Tonle Bak, and Svay Damnak, which are situated near Phnom Daek. Iron ores in sites C and $\mathrm{U}$ may have been supplied from Phnom Daek before the 13th century. Because the iron slags from the Angkor area are depleted in $\mathrm{MnO}$ and $\mathrm{MgO}$, the iron ores may have been supplied from Phnom Daek to the Angkor area. However, because iron ores with such chemical compositions are common, it cannot be concluded that the iron ores used in the Angkor area were supplied from Phnom Daek. According to the geological map of Tbeng Meanchey published in 1972 by Bureau de Recherches Géologiques et Minières of France, iron mines which were not yet investigated, are located about $5 \mathrm{~km}$ east of Phnom Kulen.

\section{Conclusions}

Chemical composition analyses using SEM-EDX were carried out for fayalite and wüstite in the iron slags and magnetite in the iron ores from the slag dumps in Preah Khan of Kompong Svay, the area surrounding Phnom Daek, and the Angkor area. On the basis of a cluster analysis and a principal component analysis using the averaged chemical compositional data for fayalite, the slag dumps were largely classified into two groups: the slag dumps in Preah Khan of Kompong Svay, except for sites $\mathrm{C}$ and $\mathrm{U}$, were classified as Groups 2, and the other slag dumps were classified as Group 1. Fayalite of Group 1 was depleted in $\mathrm{MnO}, \mathrm{MgO}$, and $\mathrm{CaO}$, except for sites $\mathrm{C}$ and $\mathrm{U}$, whereas that of Group 2 was enriched in $\mathrm{MnO}, \mathrm{MgO}$, and/or $\mathrm{CaO}$. Group 2 could be classified into five subgroups: Groups 2-A to 2-E. Fayalite in the iron slags of Groups 1 and 2 has a similar chemical compositional trend to magnetite in the iron ores of Groups 1 and 2, respectively, except for Group 2-D. Because magnetite in the iron ores in Phnom Daek is depleted in $\mathrm{MnO}$ and $\mathrm{MgO}$, Phnom Daek does not appear to have been a source of iron ores related to Group 2, except for Group 2-D of Preah Khan of Kompong Svay. The mineral chemical compositions indicate that the iron ores of Group 1 have been supplied from Phnom Daek, but as for sites $C$ and U of Group 1, iron ores may have been supplied from Phnom Daek before the 13th century. The iron ores of Group 2-D may have been supplied from an iron mine other than Phnom Daek. 
Radiocarbon dating was carried out on 10 charcoal fragments from slag dumps outside the Angkor area. A combination of dating results with those by Hendrickson et al. [7] and Pryce et al. [9], indicates that iron making in Preah Khan of Kompong Svay was conducted in and after the 13th century except for sites $C$ and $U$, where iron ores may have been supplied from Phnom Daek before the 13th century. The iron slags of Sanlong Tonle Bak (T) and Svay Damnak (F) were relatively old, and are believed to be from the 7th to the 12th centuries, but the iron slags of Sanlong Java (S) were considered younger and from the 17th to 20th centuries.

Supplementary Materials: The following are available online at http://www.mdpi.com/2571-9408/2/2/105/s1: Table S1: Chemical compositions of fayalite in iron slags by SEM-EDX., Table S2: Chemical compositions of wüstite in iron slags by SEM-EDX., and Table S3: Chemical compositions of magnetite in iron ores by SEM-EDX.

Author Contributions: Conceptualization, E.U.; Methodology, E.U.; Validation, E.U.; Formal analysis, E.U.; Investigation, E.U., M.M., A.K. and Y.L.; Resources, E.U., M.M., A.K. and Y.L.; Data curation, E.U., M.M., A.K. and Y.L.; Writing-original draft preparation, E.U.; Writing—review and editing, E.U.; Visualization, E.U., M.M., A.K. and Y.S.; Supervision, E.U.; Project administration, E.U.; Funding acquisition, E.U.

Funding: This research was supported financially in part by Grants-in-Aid for Scientific Research of the Japan Society for the Promotion of Science (Uchida: no. 23401001) and Waseda University Grants for Special Research Projects (Uchida: 2016B-137).

Acknowledgments: This research was conducted under permission of APSARA National Authority and Ministry of Culture and Fine Arts of Cambodia. We would like to express our thanks to Nobuo Yamamoto of Waseda University and Robert McCarthy of JSA for providing iron slag samples from the Angkor monuments. We are grateful to SIENG Sotham and CHENG Rathborith of Ministry of Mines and Energy of Cambodia for their help during the field research in Phnom Daek. We appreciate three anonymous reviewers for their insightful comments as well as Giada Trezzi for editorial input and suggestions. We thank Edanz Group for editing the English text of a draft of this manuscript.

Conflicts of Interest: The authors declare no conflict of interest.

\section{References}

1. Uchida, E.; Shimoda, I. Quarries and transportation routes of Angkor monument sandstone blocks. J. Archaeol. Sci. 2013, 40, 1158-1164. [CrossRef]

2. Leroy, L.; Hendrickson, M.; Bauvais, S.; Vega, E.; Blanchet, T.; Disser, A.; Delque-Kolic, E. The ties that bind: Archaeometallurgical typology of architectural crampons as a method for reconstructing the iron economy of Angkor, Cambodia (tenth to thirteenth c.). Archaeol. Anthropol. Sci. 2018, 10, 2137-2157. [CrossRef]

3. Hendrickson, M.; Leroy, S.; Hua, Q.; Phon, K.; Voeun, V. Smelting in the shadow of the iron mountain: Preliminary field investigation of the industrial landscape around Phnom Dek, Cambodia (ninth to twentieth centuries a.d.). Asian Perspect. 2017, 56, 55-91. [CrossRef]

4. Polkinghorne, M.; Vincent, B.; Thomas, N.; Bourgarit, D. Casting for the king: The Royal Palace bronze workshop of Angkor Thom. Bulletin de l'École française d'Extrême-Orient 2014, 100, 327-358. [CrossRef]

5. Aymonier, É. Le Cambodge: I. Le royaume actuel; Ernest Leroux: Paris, France, 1990; p. 47.

6. Jacques, C.; Lafond, P. The Khmer Empire: Cities and Sactuaries from the 5th to the 13th Century; River Books: Bangkok, Thailand, 2007; p. 279.

7. Hendrickson, M.; Hua, Q.; Pryce, T.O. Using in-slag charcoal as an indicator of "terminal" iron production within the Angkorian period (10th-13th Centuries AD) centre of Preah Khan of Kompong Svay, Cambodia. Radiocarbon 2013, 55, 31-47. [CrossRef]

8. Nickel, E.H. Mineral names applies to synthetic substances. Can. Mineral. 1995, 33, 1335.

9. Pryce, T.O.; Hendrickson, M.; Phon, K.; Sovichetra, C.; Charlton, M.F.; Leroy, S.; Dillmann, P.; Quan, H. The iron Kuay of Cambodia: Tracing the role of peripheral populations in Angkorian to colonial via a 1200 year old industrial landscape. J. Archaeol. Sci. 2014, 47, 142-163. [CrossRef]

10. Hendrickson, M.; Evans, D. Reimaging the city of fire and iron: A landscape archaeology of the Angkor-period industrial complex of Preah Khan of Kompong Svay, Cambodia (ca. 9th to 13th centuries A.D.). J. Field Archaeol. 2015, 40, 644-664. [CrossRef]

11. Geological Survey of Vietnam. Geological Map of Cambodia, Laos, and Vietnam (at 1:1,000,000 Scale), 2nd ed.; The Geological Survey of Vietnam: Hanoi, Vietnam, 1991. 
12. Kobayashi, K.; Niu, E.; Itoh, S.; Yamagata, H.; Lomtatidze, Z.; Jorjoliani, I.; Nakamura, K.; Jujine, H. The compact 14C AMS facility of Paleo Labo Co., Ltd., Japan. Nucl. Instrum. Methods Phys. Res. B 2007, 259, 31-35. [CrossRef]

13. Uchida, E.; Kitamura, Y.; Imai, N. Mixing properties of Fe-Mn-Mg olivine solid solution determined experimentally by ion exchange method. J. Mineral. Petrol. Econ. Geol. 1997, 92, 142-153. [CrossRef]

14. Miyamoto, Y.; Uchida, E. Experiments for the partitioning of $\mathrm{Mg}^{2+}, \mathrm{Fe}^{2+}$ and $\mathrm{Mn}^{2+}$ ions between spinel group minerals and aqueous chloride solution at $600{ }^{\circ} \mathrm{C}$ and $1 \mathrm{~kb}$. J. Mineral. Petrol. Econ. Geol. 1994, 89, 177-188. (In Japanese) [CrossRef]

(C) 2019 by the authors. Licensee MDPI, Basel, Switzerland. This article is an open access article distributed under the terms and conditions of the Creative Commons Attribution (CC BY) license (http://creativecommons.org/licenses/by/4.0/). 